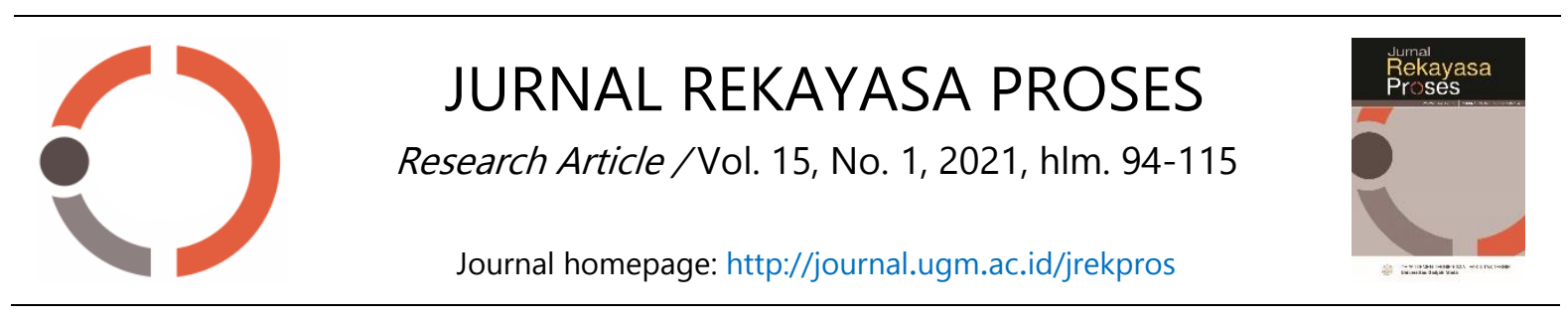

\title{
Perbandingan Performa Refrigeran Propana dan Amonia pada Siklus Refrigerasi Dew Point Control Unit (DPCU)
}

\author{
Mochammad Syahrir Isdiawan ${ }^{1 *}$, Aditya Nurfebriartanto ${ }^{1}$, dan Rafitri Rusmala ${ }^{2}$ \\ ${ }^{1}$ Program Studi Teknik Kimia, Fakultas Teknologi Industri, Institut Teknologi Bandung \\ Jalan Ganesha No. 10, Bandung, Jawa Barat, Indonesia 40132 \\ ${ }^{2}$ Departemen Teknik Kimia, Fakultas Teknik Kampus Baru, Universitas Indonesia \\ Jalan Fuad Hasan, Depok, Jawa Barat 16424 \\ * Alamat korespondensi: m.s.isdiawan@gmail.com
}

(Submisi: 19 Mei 2021; Revisi: 21 Juni 2021; Penerimaan: 2021)

\section{ABSTRACT}

Natural gas, that has been processed and met certain specifications, is sent to consumers through pipeline. Gas condensation within the pipeline should be avoided because it has negative impacts. Hydrocarbon dew point is a measure of the easiness of gas condensation. To meet the hydrocarbon dew point, heavy hydrocarbon should be extracted in dew point control unit (DPCU). The extraction is done by gas cooling in gas chiller followed by separating the liquid formed in low temperature separator (LTS). The gas chiller functions as an evaporator in the DPCU refrigeration cycle. Propane is a common refrigerant in the DPCU. In addition, ammonia is also a potential refrigerant due to its normal boiling point being close to the hydrocarbon dew point. Refrigeration cycle performance depends on evaporator temperature, condensor temperature, and the inherent pressure-enthalpy $(\mathrm{PH})$ characteristic of the selected refrigerant. This study aimed to compare the performance from ammonia and propane against the change of evaporator and condenser temperature. This study was a dry research using Aspen Hysys V11.0 simulation software (academic license). The refrigeration cycle was a simple cycle with fixed variables in the form of evaporator load, saturated liquid at outlet condenser, and saturated vapour at outlet evaporator. This study indicated that at the same evaporator load, evaporator temperature, and condenser temperature, ammonia refrigeration cycle was better than the propane because coefficient of performance (COP) of ammonia was higher than propane. This study also modeled COP changes of propane and ammonia as mathematical equation. Quantitatively, it appeared that COP of propane was more sensitive than ammonia against both evaporator and condenser temperature changes.

Keywords: ammonia; condenser; evaporator; propane; refrigeration cycle; simulation 


\section{A B STR A K}

Gas alam yang telah diolah dan sesuai spesifikasinya dikirim ke konsumen melalui pipa. Kondensasi gas dalam pipa harus dihindari karena menimbulkan dampak negatif. Titik embun hidrokarbon menjadi ukuran kemudahan proses kondensasi gas. Untuk mencapai titik embun hidrokarbon yang diinginkan, maka hidrokarbon berat harus diekstraksi di dew point control unit (DPCU). Ekstraksi dilakukan dengan cara mendinginkan gas di gas chillerlalu memisahkan cairan yang terbentuk di low temperature separator (LTS). Gas chiller tersebut berfungsi sebagai evaporator pada siklus refrigerasi DPCU. Propana adalah refrigeran yang umum digunakan di DPCU. Selain itu, amonia juga menjadi refrigeran yang potensial karena kedekatan titik didih normalnya terhadap titik embun hidrokarbon yang diinginkan. Performa siklus refrigerasi dipengaruhi oleh temperatur evaporator, temperatur kondensor, dan karakteristik tekanan-entalpi $(\mathrm{PH})$ yang melekat pada refrigeran yang dipilih. Penelitian ini bertujuan untuk membandingkan performa siklus refrigerasi propana dan amonia terhadap perubahan temperatur evaporator dan kondensor. Penelitian ini merupakan penelitian kering yang menggunakan perangkat lunak simulasi Aspen Hysys V11.0 (lisensi akademik). Siklus refrigerasi yang digunakan adalah simple cycle dengan variabel tetap berupa beban evaporator, kondisi cair jenuh outlet kondensor, dan kondisi uap jenuh outlet evaporator. Hasil penelitian ini menunjukkan bahwa pada beban evaporator, temperatur evaporator, dan temperatur kondensor yang sama, maka siklus refrigerasi amonia lebih baik dari propana karena COP amonia lebih tinggi dari propana. Penelitian ini juga memodelkan nilai COP propana dan amonia sebagai persamaan matematika. Secara kuantitatif, terlihat bahwa COP amonia lebih stabil dari propana terhadap perubahan temperatur evaporator dan kondensor.

Kata kunci: amonia; evaporator; kondensor; propana; siklus refrigerasi; simulasi

\section{Pendahuluan}

Gas alam (natural gas) adalah gas hidrokarbon yang terdiri atas metana sebagai komponen penyusun utama, hidrokarbon lain dalam jumlah yang bervariasi, dan sedikit gas selain hidrokarbon seperti karbon dioksida, nitrogen, atau hidrogen sulfida. Gas alam termasuk bahan bakar fosil yang polusinya lebih kecil dibandingkan dengan batu bara dan minyak bumi (Lim dkk., 2013). Gas alam akan terus menjadi sumber bahan bakar utama selama belum ada teknologi produksi gas hidrogen yang ekonomis untuk fuel cell (Hidayat dkk., 2020).

Gas alam diambil dari sumur lalu diproses lebih lanjut di fasilitas pengolahan gas. Pada fasilitas tersebut, gas alam dikondisikan supaya memenuhi spesifikasi laju alir, tekanan, temperatur, komposisi, nilai kalor, dan titik embun (dew point) yang diminta oleh konsumen. Gas alam yang telah siap dikirim ke konsumen dinamakan gas jual (sales gas). Sistem transportasi sales gas merupakan aspek esensial karena lokasi konsumen yang mungkin jauh dari fasilitas pengolahan gas. Pipeline menjadi alat transportasi gas yang ekonomis, aman, dan handal.

Titik embun hidrokarbon (hydrocarbon dew point) menjadi salah satu parameter proses yang vital pada sales gas. Titik embun didefinisikan sebagai temperatur tertinggi saat terjadi proses kondensasi. Titik embun yang rendah membuat transportasi sales gas menjadi aman karena terhindar dari pembentukan cairan di sepanjang jalur pipa 
gas (Shoaib dkk., 2018). Keberadaan cairan dalam pipeline harus dihindari karena dapat menimbulkan potensi tersumbatnya aliran gas, kerusakan peralatan, dan kebocoran pipa gas (Makogon, 2010; Nasir dkk., 2020). Untuk menghindari pembentukan cairan, maka hydrocarbon dew point harus diatur sedemikian rupa sehingga nilainya lebih rendah dibandingkan temperatur terendah dalam proses transportasi gas. Untuk mencapai dew point tersebut, hidrokarbon berat yang umumnya $C_{6+}$ perlu dipisahkan dari aliran gas (Elhady, 2005). Ekstraksi hidrokarbon berat tersebut dapat dilakukan dengan cara refrigerasi mekanik dan ekspansi secara isentalpik maupun isentropik (Elyas dan Li, 2017; Aftab dkk., 2016). Untuk selanjutnya, penelitian ini mengkaji proses refrigerasi mekanik pada unit ekstraksi hidrokarbon berat yang bernama Dew Point Control Unit (DPCU).

Di DPCU, gas umpan mendapat injeksi lean hydrate inhibitor terlebih dahulu untuk menurunkan temperatur minimal pembentukan hidrat (Hidayat dkk., 2020). Gas umpan kemudian masuk gas/gas exchanger untuk mentransferkan panasnya ke sales gas dan menaikkan temperatur sales gas. Gas umpan yang menjadi lebih dingin selanjutnya didinginkan lebih lanjut di gas chiller. Pada gas chiller, refrigeran bertugas mengambil panas gas umpan sampai mencapai hydrocarbon dew point yang diinginkan. Produk gas chiller tersebut mengandung 3 fasa yang kemudian dipisahkan masingmasing pada low temperature separator(LTS). Larutan hydrate inhibitor yang mengandung pengotor berupa air $\left(\mathrm{H}_{2} \mathrm{O}\right)$ selanjutnya dikirim ke hydrate inhibitor recovery unit. Hidrokarbon berat yang telah terpisah dari gas umpan dikirim ke unit pengolahan kondensat. Produk gas dari LTS kemudian masuk ke gas/gas exchanger lalu ke pipeline untuk dikirim ke konsumen.

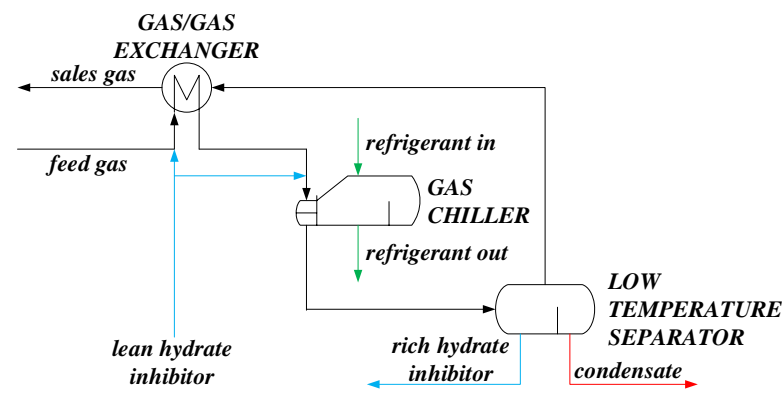

Gambar 1. Diagram Alir Proses Ekstraksi Gas Alam pada Dew Point Control Unit

Gas chiller pada DPCU berfungsi sebagai evaporator bagi refrigeran. Refrigeran tersebut beroperasi pada siklus refrigerasi yang memanfaatkan hukum termodinamika berupa pemberian kerja eksternal untuk memindahkan sejumlah energi panas. Siklus refrigerasi menggunakan prinsip siklus kompresi uap (vapor-compression cycle) yang melibatkan alat peningkat tekanan, kondensor untuk mengubah uap refrigeran menjadi cair, alat ekspansi untuk mengembalikan tekanan refrigeran, dan evaporator untuk mendapatkan kembali uap refrigeran. Performa ekstraksi gas alam bergantung pada performa siklus refrigerasi. Performa sistem refrigerasi diukur dengan coefficient of performance (COP) yaitu rasio beban evaporator terhadap kerja yang diberikan pada sistem. Nilai COP yang semakin tinggi menunjukkan kerja siklus refrigerasi yang semakin bagus. Secara umum, COP dihitung menggunakan Persamaan (1).

$C O P=\frac{\text { Kalor yang diserap evaporator }}{\text { Kerja netto yang diberikan }}=\frac{Q_{\text {in }}}{W}$ 


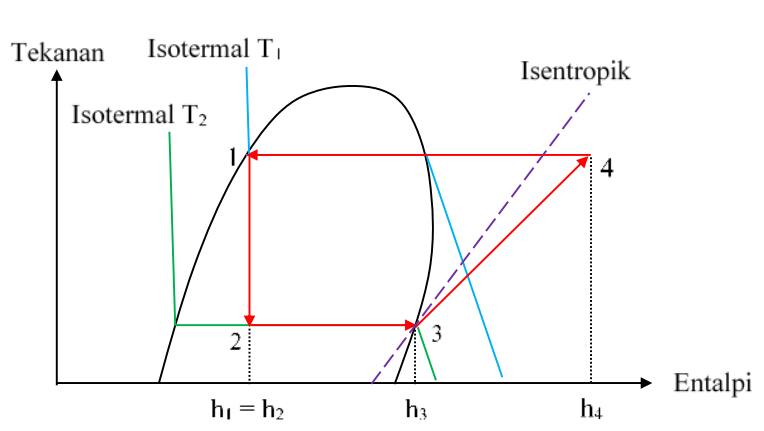

Gambar 1. Tipikal diagram tekanan-entalpi $(P-H)$ pada siklus refrigerasi

Kalor yang diserap oleh refrigeran pada gas chiller sama dengan beban evaporator. beban evaporator $\left(Q_{\text {in }}\right)$ ditunjukkan oleh selisih antara entalpi outlet evaporator $\left(h_{3}\right)$ dengan entalpi inlet evaporator $\left(h_{2}\right)$. Besar kerja yang diberikan (W) adalah selisih antara entalpi outlet kompresor $\left(h_{4}\right)$ dengan entalpi inlet kompresor $\left(h_{3}\right)$. Persamaan (1) dapat ditulis ulang sebagai Persamaan (2).

$$
C O P=\frac{Q_{\text {in }}}{W}=\frac{M\left(h_{3}-h_{2}\right)}{M\left(h_{4}-h_{3}\right)}=\frac{h_{3}-h_{2}}{h_{4}-h_{3}}
$$

Kondisi 1 berada pada kondisi cair jenuh (saturated liquid) dan nilai $\mathrm{h}_{1}$ bersifat spesifik untuk temperatur $\mathrm{T}_{1}$. Proses 1-2 adalah proses ekspansi isentalpik sehingga nilai $h_{1}$ sama dengan $h_{2}$. Kondisi 3 adalah kondisi uap jenuh (saturated vapour). Gambar 2 menunjukkan bahwa temperatur $\mathrm{T}_{2}$ yang berbeda memberikan nilai $h_{3}$ yang berbeda pula. Nilai $\mathrm{h}_{4}$ bergantung pada tekanan akhir yang ingin dicapai dan efisiensi isentropik yang didapat.

Persamaan (2) menunjukkan bahwa COP merupakan besaran intensif karena tidak bergantung pada laju alir refrigeran. Gambar 2 juga memperlihatkan bahwa jika $T_{1}$ dan $T_{2}$ bernilai konstan, maka COP juga bernilai konstan. Artinya, saat terjadi perubahan beban evaporator pada $T_{1}$ dan $T_{2}$ yang tetap, maka siklus refrigerasi memberikan respon berupa penambahan atau pengurangan laju alir refrigeran. Perubahan laju alir tersebut berpengaruh linier pada kerja kompresor. Oleh karena itu, perubahan beban evaporator sebanding dengan perubahan kerja kompresor sehingga nilai COP tetap.

Nilai $h_{1}$ dan $h_{3}$ merupakan perpotongan antara garis isotermal dan diagram $\mathrm{P}-\mathrm{H}$. Pergeseran titik perpotongan tersebut dapat mengubah nilai $h_{1}$ dan $h_{3}$. Garis isotermal dapat bergeser jika terjadi perubahan temperatur $T_{1}$ dan/atau $T_{2}$. $T_{1}$ dan $T_{2}$ berturutturut adalah temperatur kondensasi dan evaporasi refrigeran. Pada siklus refrigerasi, kedua temperatur tersebut merupakan temperatur kondensor dan evaporator. Titik perpotongan juga dapat berubah jika terjadi perubahan diagram $\mathrm{P}-\mathrm{H}$. Diagram $\mathrm{P}-\mathrm{H}$ berubah jika terjadi perubahan refrigeran karena diagram $\mathrm{P}-\mathrm{H}$ bersifat spesifik untuk setiap refrigeran. Oleh karena itu, dapat disimpulkan bahwa temperatur kondensor, temperatur evaporator, dan komponen penyusun refrigeran adalah faktor yang mempengaruhi COP.

Performa siklus refrigerasi menentukan kerja DPCU pada ekstraksi hidrokarbon berat. Supaya DPCU bekerja dengan baik, maka siklus refrigerasi harus dirancang supaya menghasilkan COP yang tinggi. Selain itu, siklus refrigerasi harus aman jika ditinjau dari aspek health, safety, and environment (HSE). Terakhir, siklus refrigerasi harus memiliki performa yang stabil terhadap perubahan temperatur kondensor dan/atau evaporator. Dalam hal perubahan temperatur kondensor dan evaporator, maka performa stabil yang dimaksud adalah performa yang tidak berubah signifikan terhadap kondisi design (base case).

Pada perancangan siklus refrigerasi, salah satu langkah pertama yang dilakukan adalah 
menentukan komposisi penyusun refrigeran karena berhubungan dengan diagram $\mathrm{P}-\mathrm{H}$ yang digunakan. Refrigeran diklasifikasikan menjadi 4 tipe, yaitu inorganik, hidrokarbon, chlorofluorocarbons (CFC), dan hydrochlorofluorocarbons (HCFC) (Horbaniuc, 2004; Mokhatab dkk., 2014). Penggunaan refrigeran dari kelas CFC dan HCFC sudah dilarang penggunaannya melalui WHO technical report series no. 961- Supplement 16 karena menyebabkan kerusakan pada lapisan ozon dan memiliki potensi meningkatkan pemanasan global yang tinggi. Oleh karena itu, tipe refrigeran yang dapat dipilih hanya senyawa inorganik dan hidrokarbon.

Tabel 1. 'Klasifikasi dan Sifat Fisik Refrigeran (Horbaniuc, 2004; Smith dkk., 2018)

\begin{tabular}{|c|c|c|c|c|c|}
\hline No & $\begin{array}{l}\text { Nama } \\
\text { Kimia }\end{array}$ & $\begin{array}{l}\text { Rumus } \\
\text { Kimia }\end{array}$ & Kode & $\begin{array}{c}\text { Titik Didih } \\
\text { Normal } \\
\left({ }^{\circ} \mathrm{C}\right)\end{array}$ & $\begin{array}{c}\text { Temperatur } \\
\text { Kritis }\left({ }^{\circ} \mathrm{C}\right)\end{array}$ \\
\hline \multicolumn{6}{|c|}{ Inorganik } \\
\hline 1. & Air & $\mathrm{H}_{2} \mathrm{O}$ & - & 100,0 & 374,0 \\
\hline 2. & $\begin{array}{l}\text { Sulfur } \\
\text { Dioksida }\end{array}$ & $\mathrm{SO}_{2}$ & R-764 & $-10,0$ & 157,7 \\
\hline 3. & Amonia & $\mathrm{NH}_{3}$ & $\mathrm{R}-717$ & $-33,4$ & 132,6 \\
\hline 4. & $\begin{array}{l}\text { Karbon } \\
\text { Dioksida }\end{array}$ & $\mathrm{CO}_{2}$ & $\mathrm{R}-744$ & $-78,5$ & 31,1 \\
\hline \multicolumn{6}{|c|}{ Hidrokarbon } \\
\hline 5. & Isobutana & $\mathrm{i}-\mathrm{C}_{4} \mathrm{H}_{10}$ & $R-600$ & $-11,7$ & 135,0 \\
\hline 6. & Propana & $\mathrm{C}_{3} \mathrm{H}_{8}$ & $\mathrm{R}-290$ & $-42,3$ & 96,7 \\
\hline 7. & Propilena & $\mathrm{C}_{3} \mathrm{H}_{6}$ & $R-1270$ & $-47,7$ & 92,5 \\
\hline 8. & Etana & $\mathrm{C}_{2} \mathrm{H}_{6}$ & $\mathrm{R}-170$ & $-88,6$ & 32,2 \\
\hline 9. & Etilena & $\mathrm{C}_{2} \mathrm{H}_{4}$ & $R-1150$ & $-103,5$ & 9,2 \\
\hline 10. & Metana & $\mathrm{CH}_{4}$ & $\mathrm{R}-50$ & $-161,5$ & $-82,6$ \\
\hline
\end{tabular}

Menurut Mokhatab dkk. (2014), refrigeran yang dipilih harus memiliki temperatur kritis yang tidak terlalu rendah supaya dapat dikondensasi pada temperatur atmosferis atau temperatur menengah ke bawah. Mokhatab dkk. (2014) juga menjelaskan bahwa refrigeran harus memiliki tekanan jenuh yang sedikit lebih tinggi dari tekanan atmosfer pada rentang temperatur evaporator yang diinginkan. Hal ini berarti titik didih normal refrigeran harus sedikit lebih rendah dari rentang temperatur evaporator yang diinginkan.

Di DPCU, refrigeran mengambil panas dari gas alam di gas chiller sampai mencapai hydrocarbon dew point yang diinginkan. Gas chiller tersebut berfungsi sebagai evaporator bagi refrigeran. Gas chiller umumnya merupakan shell and tube dengan tipe kettle (Aftab dkk., 2016). Shell and tube memiliki minimum temperature difference sebesar $10^{\circ} \mathrm{C}$ (Smith, 2005). Untuk mencapai tipikal nilai hydrocarbon dew point sebesar $-10^{\circ} \mathrm{C}$ (Mokhatab dkk., 2017), maka evaporator harus beroperasi pada suhu $-20^{\circ} \mathrm{C}$. Untuk refrigeran hidrokarbon, propana adalah refrigeran yang titik didih normalnya paling mendekati temperatur tersebut sehingga cocok digunakan di DPCU. Banyak penelitian yang menyebutkan bahwa propana umum digunakan sebagai refrigeran pada DPCU (Aftab dkk., 2016; Al Shehhi dkk., 2019; El Mawgoud dkk., 2015). Pada refrigeran inorganik, amonia memiliki titik didih normal yang paling dekat dengan kriteria suhu $-20^{\circ} \mathrm{C}$. Berdasarkan panduan awal dalam memilih refrigeran (Mokhatab dkk., 2014), amonia lebih cocok menjadi refrigeran DPCU. Hal ini juga didukung oleh penelitian lainnya yang menyebutkan bahwa amonia menghasilkan COP yang lebih tinggi dari propana (Chebbi dkk., 2013; Nawaz dkk., 2018).

Siklus refrigerasi harus aman digunakan dari aspek HSE. Untuk itu, perlu dibandingkan karakteristik sifat pembakaran amonia dan propana. Amonia memiliki LFL (lower flammability limit) yang lebih tinggi dan rentang batas pembakaran yang lebih sempit dibandingkan propana. Selain itu, amonia memiliki nilai auto ignition temperature dan minimum ignition energy yang lebih tinggi 
dari propana. Semua fakta tersebut menunjukkan bahwa saat terjadi kebocoran dari peralatan ke udara, maka amonia lebih sulit terbakar jika dibandingkan dengan propana. Berdasarkan kecepatan rambatan api, maka api dari kebakaran amonia merambat lebih lambat dari propana karena nilai laminar burning velocity amonia lebih kecil dari propana. Dari kemudahan manusia dalam mendeteksi bocoran, maka kebocoran amonia lebih mudah dideteksi daripada propana karena amonia memiliki bau yang khas tidak seperti propana. Kekurangan amonia sebagai refrigeran adalah amonia merupakan racun yang lebih berbahaya untuk kesehatan manusia karena skor health risk dari NFPA untuk amonia lebih tinggi dari propana.

Tabel 2. Perbandingan sifat pembakaran amonia dan propana (Eckhoff dkk., 2010; Kobayashi dkk., 2019; MSDS; Verkamp dkk., 1967)

\begin{tabular}{llcc}
\hline No & \multicolumn{1}{c}{ Parameter } & Amonia & Propana \\
\hline 1. & Flammability limit & $0,63-1,40$ & $0,51-2,50$ \\
2. & $\begin{array}{l}\text { Minimum auto ignition } \\
\text { temperature }\left({ }^{\circ} \mathrm{C}\right)\end{array}$ & 650 & 450 \\
3. & Minimum ignition energy $(\mathrm{MJ})$ & 680 & 0,48 \\
4. $\quad$ Maximum laminar burning & 7 & 43 \\
& velocity $(\mathrm{cm} / \mathrm{s})$ & & \\
5. & LHV $(\mathrm{MJ} / \mathrm{kg})$ & 18,6 & 46,4 \\
6. & Bau & Berbau & $\begin{array}{c}\text { Tidak } \\
\text { berbau } \\
\text { 7. }\end{array}$ \\
& NFPA Health Risk & 3 & 2 \\
\hline
\end{tabular}

Performa siklus refrigerasi diharapkan tidak berubah signifikan terhadap perubahan temperatur evaporator dan/atau kondensor. Temperatur evaporator mengikuti hydrocarbon dew point sales gas yang diinginkan. Saat terjadi perubahan temperatur tersebut, tentu terjadi perubahan kalor laten refrigeran di evaporator, tekanan operasi, dan COP sesuai Gambar 2. Di kondensor, temperatur operasinya dapat berubah karena bergantung pada medium pendingin yang digunakan. Elyas dan Li (2017) mengasumsikan cooling water atau udara atmosfer sebagai medium pendingin kondensor yang temperaturnya mengikuti temperatur lingkungan. Temperatur lingkungan dapat berubah saat pagi, siang, dan malam hari. Saat temperatur lingkungan berubah, maka tekanan kondensor berubah sehingga COP, kalor laten refrigeran di kondensor, dan kalor laten refrigeran di evaporator juga berubah sesuai penjelasan Gambar 2.

Perubahan tekanan evaporator dan/atau kondensor berpengaruh pada kerja kompresor dan COP. Kalor laten di evaporator yang berubah dapat mempengaruhi performa gas chiller di DPCU sehingga berpengaruh pada hydrocarbon dew point sales gas. Jika siklus refrigerasi DPCU yang telah terpasang tidak dapat memenuhi performa proses saat terjadi perubahan temperatur evaporator dan/atau kondensor, maka ada kemungkinan diperlukan proses debottlenecking. Oleh karena itu, diperlukan analisis perubahan temperatur evaporator dan/atau kondensor terhadap parameter proses siklus refrigerasi. Hal tersebut bermanfaat dalam hal menentukan refrigeran yang performanya stabil terhadap perubahan kedua temperatur tersebut.

Penelitian terhadap pengaruh beban dan temperatur evaporator pada refrigeran amonia dan propana telah dilakukan oleh Chebbi dkk. (2013). Chebbi dkk. (2013) belum mempertimbangkan perubahan temperatur kondensor. Karena temperatur kondensor mengikuti temperatur lingkungan, maka temperatur kondensor dapat berubah baik saat ada perubahan temperatur evaporator maupun tidak. Penelitian ini bertujuan untuk 
meneliti pengaruh perubahan temperatur evaporator dan kondensor terhadap performa propana dan amonia pada siklus refrigerasi DPCU. Tujuan lain yang ingin dicapai adalah memodelkan performa siklus refrigerasi propana dan amonia terhadap kedua perubahan temperatur tersebut. Penelitian ini menggunakan simple cycle seperti yang digunakan oleh Elyas dan Li (2017) karena penelitian ini hanya ingin mengkaji pengaruh perubahan temperatur evaporator dan kondensor.

\section{Metode Penelitian}

Penelitian ini merupakan penelitian kering (dry research) menggunakan perangkat lunak komputasi proses. Supaya dapat membandingkan performa refrigeran propana dan amonia pada siklus refrigerasi DPCU, maka dipilih alat dan bahan penelitian serta cara penelitian sebagai berikut.

\subsection{Alat dan Bahan Penelitian}

Penelitian ini menggunakan perangkat lunak Aspen Hysys V11.0 (lisensi akademik ITB). Komponen yang digunakan sebagai bahan penyusun refrigeran adalah propana murni dan amonia murni.

\subsection{Cara Penelitian}

Untuk mencapai tujuan, maka penelitian ini dilakukan pada sebuah proses tertentu dengan membatasi variabel tetap dan variabel bebasnya serta dengan memberikan basis dan asumsi untuk memudahkan pemodelan. Deskripsi proses, pemilihan variabel tetap dan bebas, serta penggunaan basis dan asumsi dijelaskan lebih lanjut sebagai berikut.

\subsubsection{Deskripsi Proses}

Penelitian ini memodelkan siklus refrigerasi DPCU sebagai sebuah simple cycle (Elyas dan Li, 2017). Refrigeran (aliran 1) bertekanan tinggi pada kondisi cair jenuh (saturated liquid) mengalami ekspansi di JT valve. Ekspansi ini menyebabkan sebagian refrigeran menguap. Keluaran JT valve (aliran 2) selanjutnya mendapatkan panas dari gas alam di evaporator sehingga berada pada kondisi uap jenuh (saturated vapour). Uap refrigeran (aliran 3) dinaikkan tekanannya menggunakan kompresor lalu dicairkan kembali di kondensor. Keluaran kondensor tersebut (aliran 1) kembali masuk ke $J T$ valve sesuai penjelasan sebelumnya.

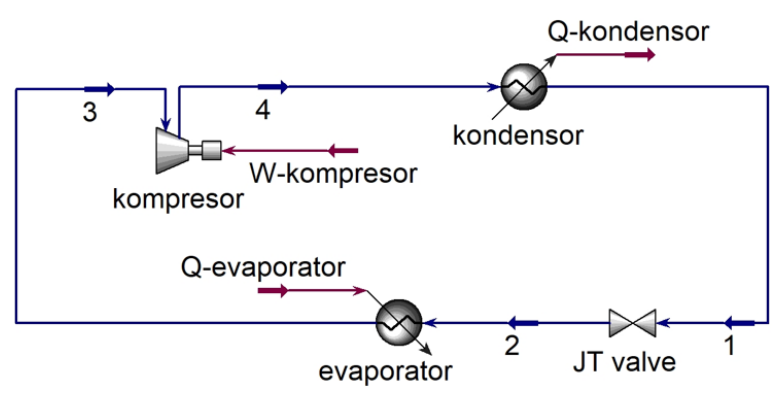

Gambar 2. Diagram alir proses refrigerasi simple cycle

\subsubsection{Variabel Tetap dan Bebas}

Variabel yang dibuat tetap adalah beban evaporator sebesar $100 \mathrm{~kW}$, kondisi produk kondensor (aliran 1) yang berupa cair jenuh, dan produk evaporator (aliran 3) yang berada dalam kondisi uap jenuh. Kondisi cair jenuh tersebut dimodelkan dengan cara memberikan nilai 0 pada vapour fraction aliran 1. Untuk uap jenuh, diberikan nilai 1 pada aliran 3.

Variabel bebas yang dipilih adalah temperatur operasi evaporator (aliran 3) dan temperatur operasi kondensor (aliran 4). Karena penelitian ini mengkaji perubahan temperatur evaporator dan kondensor, maka perlu ditetapkan nilai yang menjadi base case 
temperatur evaporator dan kondensor. Nilai tipikal hydrocarbon dew point adalah $-10^{\circ} \mathrm{C}$ (Mokhatab dkk., 2017). Karena minimum temperature difference pada evaporator berbentuk shell and tube adalah $10^{\circ} \mathrm{C}$ (Smith, 2005), maka base case temperatur operasi evaporator ditetapkan sebesar $-20^{\circ} \mathrm{C}$. Kondensor diasumsikan sebagai sebuah unit shell and tube dengan medium pendingin berupa cooling water yang tersedia pada rentang suhu $30-40^{\circ} \mathrm{C}$ (Elyas dan Li, 2017). Dipilih satu buah temperatur pada rentang tersebut, yaitu $30^{\circ} \mathrm{C}$. Dengan minimum temperature difference sebesar $10^{\circ} \mathrm{C}$, maka base case temperatur kondensor adalah $40^{\circ} \mathrm{C}$. Kedua temperatur operasi tersebut dibuat bervariasi dengan cara dinaikkan atau diturunkan maksimal $5^{\circ} \mathrm{C}$. Dari penjelasan tersebut, maka temperatur operasi evaporator berada pada rentang $-25^{\circ} \mathrm{C}$ dan $15^{\circ} \mathrm{C}$ sedangkan temperatur operasi kondensor berada pada rentang $35^{\circ} \mathrm{C}$ dan $45^{\circ} \mathrm{C}$.

Komponen penyusun refrigeran juga menjadi variabel bebas pada penelitian ini. Variasi yang ditetapkan untuk komponen penyusun refrigeran hanya 2 macam, yaitu: refrigeran yang mengandung amonia dan yang mengandung propana.

\subsubsection{Basis dan Asumsi}

Karena refrigeran merupakan komponen tunggal dan siklus refrigerasi banyak bekerja pada kondisi jenuh (saturated) dan kesetimbangan 2 fasa, maka model termodinamika yang dipilih adalah tipe persamaan keadaan (equation of state) yaitu Peng-Robinson. Model termodinamika PengRobinson tersebut sesuai dengan rekomendasi Aspen Hysys V11.0 pada fitur methods assistant Aspen Hysys V11.0 untuk oil and gas processing.

Siklus refrigerasi DPCU dapat memiliki ruang lingkup dan variabel yang luas sehingga harus diberikan asumsi. Asumsi yang digunakan pada penelitian ini antara lain:

1. Siklus refrigerasi dimodelkan sebagai simple cycle.

2. Siklus refrigerasi berada pada kondisi tunak (steady state).

3. Hilang tekan pada evaporator, kondensor, pipa, dan fitting diabaikan.

4. Efisiensi pertukaran panas pada kondensor dan evaporator bernilai $100 \%$.

5. Tipe kompresor yang digunakan adalah sentrifugal dengan efisiensi adiabatik sebesar $75 \%$.

6. Tidak ada pengotor pada refrigeran.

\subsubsection{Algoritma Percobaan}

Tujuan penelitian ini dapat dicapai jika melakukan prosedur percobaan sesuai algoritma yang ditetapkan. Algoritma percobaan ditampilkan pada Gambar 4 dalam bentuk diagram alir.

\subsubsection{Persamaan Matematika yang Digunakan}

Aspen Hysys adalah salah satu perangkat lunak simulasi proses yang mempermudah perhitungan. Dalam menghitung, Aspen Hysys menggunakan persamaan matematika untuk mendapatkan hasil sesuai berdasarkan nilai yang dimasukkan. Semua persamaan matematika yang ditulis pada penelitian ini merujuk pada fitur help Aspen Hysys V11.0. Pada siklus refrigerasi simple cycle yang melibatkan kondensor, JT valve, evaporator, dan kompresor, persamaan matematika yang digunakan adalah sebagai berikut. 


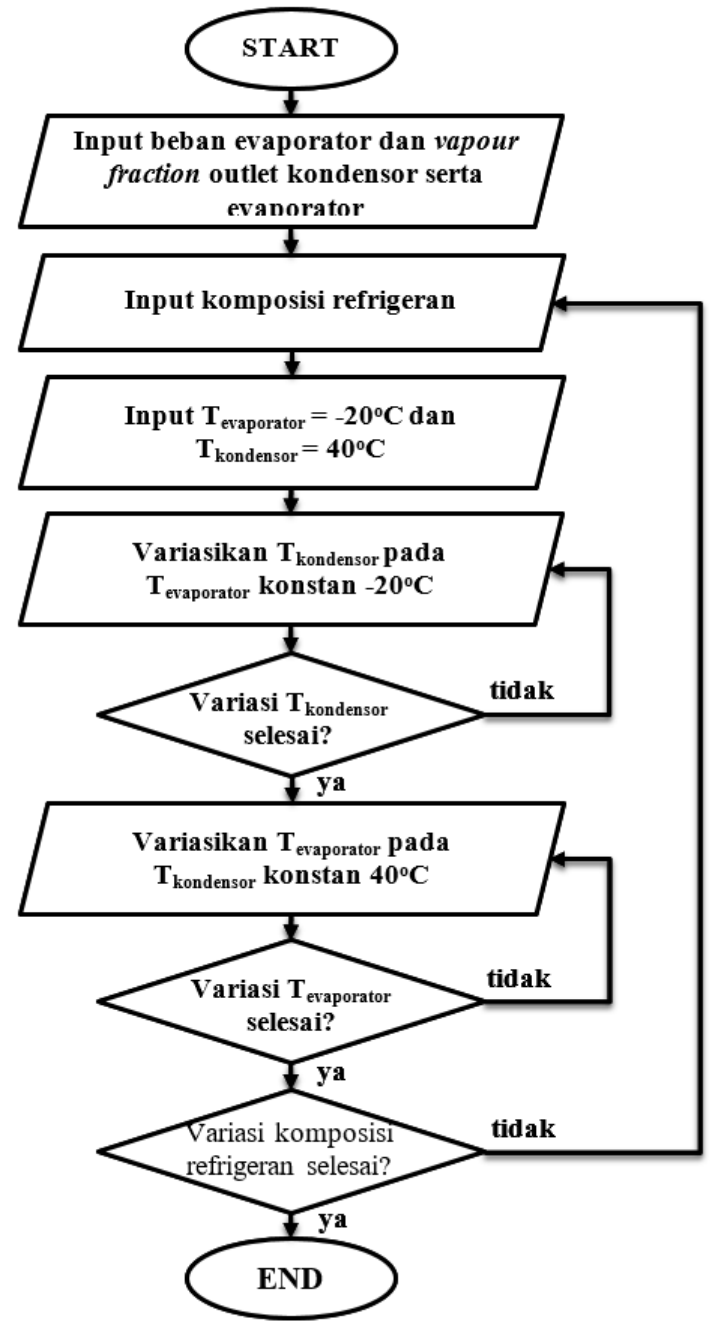

Gambar 3. Algoritma percobaan

1. Kondensor

Pada siklus refrigerasi simple cycle, fluida masuk kondensor berada pada kondisi uap lewat jenuh (superhated vapour) dan keluar kondensor pada kondisi cair jenuh (saturated liquid). Input yang diberikan adalah vapour fraction dan temperatur. Untuk menghitung tekanan jenuh, digunakan persamaan Antoine (Persamaan (3)).

$\ln P_{\text {sat }}=A+\frac{B}{T+C}+D \ln T+E T^{F}$

Kondensor dimodelkan sebagai sebuah cooler. Persamaan matematika yang digunakan pada cooler ditampilkan pada Persamaan (4).
$M\left(H_{\text {in }}-H_{\text {out }}\right)-Q_{\text {cooler }}=\rho \frac{d\left(V H_{\text {out }}\right)}{d t}$

Entalpi gas dihitung menggunakan Persamaan (5).

$H_{g}-H_{g}^{\text {ref }}=\int_{298,15}^{T} C p^{I G} d T+\Delta H_{\text {equation of state }}$

Karena menggunakan Peng-Robinson sebagai fluid package, maka nilai $\Delta H_{\text {equation }}$ of state dihitung menggunakan Persamaan (6) dan dengan bantuan Persamaan (7) (11).

$$
\begin{aligned}
& \frac{\Delta H_{\text {equation of state }}}{R T}=Z-1- \\
& \frac{1}{2^{1,5} b R T}\left[\begin{array}{c}
a \\
-T \frac{d a}{d t}
\end{array}\right] \ln \left[\frac{V+\left(2^{0,5}+1\right) b}{V+\left(2^{0,5}-1\right) b}\right] \\
& b=0,077796 \frac{R T_{c}}{P_{c}} \\
& a=a_{c} \alpha \\
& a_{c}=0,457235 \frac{\left(R T_{c}\right)^{2}}{P_{c}}
\end{aligned}
$$

$m=0,37646+1,54226 \omega-0,26992 \omega^{2}$

Entalpi pada kondisi cair jenuh dihitung menggunakan Persamaan (12).

$H_{l}^{s a t}=H_{l}^{r e f}+\int_{T^{r e f}}^{T} C p_{l} d T$

\section{JT Valve}

JT valve bekerja pada kondisi isentalpik sehingga berlaku Persamaan (13).

$H_{\text {in }}=H_{\text {out }}$

3. Evaporator

Evaporator dimodelkan sebagai sebuah heater. Persamaan (14) menunjukkan 
persamaan matematika yang digunakan pada heater.

$M\left(H_{\text {in }}-H_{\text {out }}\right)+Q_{\text {heater }}=\rho \frac{d\left(V H_{\text {out }}\right)}{d t}$

Fluida masuk evaporator dalam kondisi kesetimbangan dua fasa (uap-cair) dan keluar dalam keadaan uap jenuh. Karena temperatur keluar evaporator diketahui, maka tekanan operasi evaporator dapat dihitung menggunakan Persamaan

Entalpi uap jenuh dihitung menggunakan persamaan (5) - (11) karena masih berada pada fasa uap. Entalpi masuk evaporator sama dengan entalpi keluar $J T$ valve sehingga dapat dihitung dari Persamaan (13).

4. Kompresor

Kompresor yang digunakan adalah tipe sentrifugal sehingga berlaku Persamaan (15) dan (16).

$\frac{T_{\text {out }}}{T_{\text {in }}}=\left(\frac{P_{\text {out }}}{P_{\text {in }}}\right)^{\frac{\gamma-1}{\gamma}}$

$W=\frac{1}{\eta_{\text {polytropic }}} Z_{\text {in }} R T_{\text {in }} \frac{\gamma}{\gamma-1}\left[\left(\frac{P_{\text {out }}}{P_{\text {in }}}\right)^{\frac{\gamma-1}{\gamma}}-1\right]$

$\gamma=\frac{C p}{C v}$

Peng-Robinson menghitung compressibility factor ( $Z$ ) menggunakan Persamaan (18) dengan cara iterasi.

$Z^{3}-\left(1-K_{1}\right) Z^{2}+\left(K_{1}-2 K_{2}-3 K_{2}{ }^{2}\right) Z-$

$\left(K_{1} K_{2}-K_{2}^{2}-K_{2}^{3}\right)=0$

$K_{1}$ dan $K_{2}$ dapat dihitung menggunakan Persamaan (19) dan (20).

$K_{1}=\frac{a P}{(R T)^{2}}$

$K_{2}=\frac{b P}{R T}$
Nilai a dan b didapat dari persamaan (7) (11).

\section{Hasil dan Pembahasan}

Pemodelan dan simulasi menggunakan Aspen Hysys V11.0 dilakukan untuk membandingkan performa siklus refrigerasi antara propana dan amonia terhadap perubahan temperatur evaporator dan kondensor. Dalam membandingkan performa antar refrigeran, maka dilakukan analisa diagram tekanan-temperatur (diagram P-T), diagram tekanan-entalpi (diagram $\mathrm{P}-\mathrm{H}$ ), parameter proses siklus refrigerasi, dan analisis sensitivitas parameter proses terhadap perubahan temperatur kondensor dan evaporator.

\subsection{Validasi}

Penelitian ini menggunakan refrigeran propana dan simple cycle seperti yang dilakukan oleh Elyas dan Li (2017). Elyas dan Li (2017) menggunakan perangkat lunak simulasi UniSim dengan fluid package PengRobinson. Untuk keperluan validasi, maka semua input yang dilakukan oleh Elyas dan Li (2017) juga dimasukkan pada penelitian ini sesuai Tabel 3. Hasil simulasi penelitian ini menghasilkan selisih antara $0,1 \%-1,3 \%$ sehingga model simulasi yang digunakan sudah valid dan dapat digunakan untuk evaluasi selanjutnya.

\subsection{Karakteristik Tekanan-Temperatur (P-T) Propana dan Amonia}

Siklus refrigerasi melibatkan proses perubahan fasa refrigeran pada kondensor dan evaporator. Perubahan dari uap lewat jenuh menjadi cair jenuh terjadi di kondensor 
Tabel 3. Validasi hasil simulasi

\begin{tabular}{|c|c|c|c|c|c|}
\hline No & Parameter & Satuan & Elyas dan Li (2017) & Penelitian ini & Selisih \\
\hline \multicolumn{6}{|c|}{ INPUT } \\
\hline 1. & Kemurnian propana & - & $100 \%$ & $100 \%$ & - \\
\hline 2. & Pressure drop kondensor & bar & 0 & 0 & - \\
\hline 3. & Vapour fraction outlet kondensor & - & 0 & 0 & - \\
\hline 4. & Temperatur outlet kondensor & ${ }^{\circ} \mathrm{C}$ & 50 & 50 & - \\
\hline 5. & Pressure drop evaporator & bar & 0 & 0 & - \\
\hline 6. & Vapour fraction outlet evaporator & - & 1 & 1 & - \\
\hline 7. & Beban evaporator & kW & 340 & 340 & - \\
\hline 8. & Efisiensi adiabatik kompresor & - & $100 \%$ & $100 \%$ & - \\
\hline \multicolumn{6}{|c|}{ OUTPUT } \\
\hline 9. & Laju alir refrigeran & $\mathrm{kg} / \mathrm{jam}$ & 5832 & 5825 & $0,1 \%$ \\
\hline 10. & Kerja kompresor & kW & 150 & 148,1 & $1,3 \%$ \\
\hline 11. & Beban kondensor & kW & 490 & 488,1 & $0,4 \%$ \\
\hline
\end{tabular}

sedangkan cairan menjadi uap jenuh berlangsung di evaporator. Karena temperatur operasi kondensor dan evaporator telah diketahui, maka tekanan operasi kedua peralatan tersebut dapai dicari. Hubungan tekanan dan temperatur jenuh dapat digambarkan pada sebuah diagram tekanan-temperatur (P-T). Diagram P-T propana dan amonia dibuat menggunakan fitur envelope pada stream analysis Aspen Hysys V11.0.

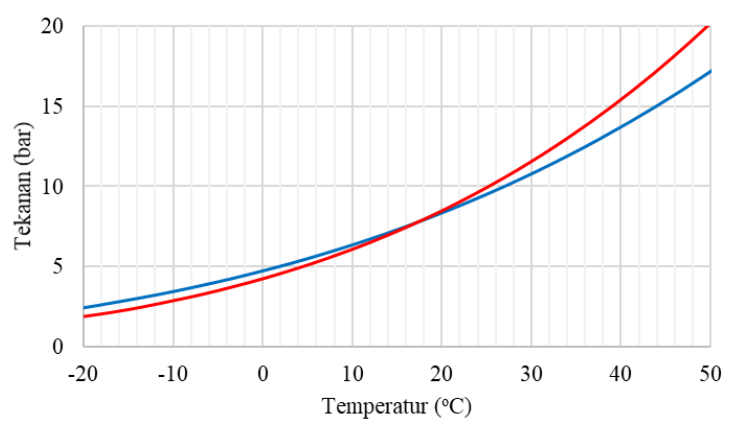

- Propana - Amonia

Gambar 4. Diagram P-T propana dan amonia

Pada temperatur kurang dari $18^{\circ} \mathrm{C}$, tekanan jenuh propana lebih tinggi dari amonia. Untuk temperatur yang lebih tinggi dari $18^{\circ} \mathrm{C}$, amonia memiliki tekanan jenuh yang lebih tinggi dari propana. Karena evaporator beroperasi pada suhu $-20^{\circ} \mathrm{C}$ dan kondensor pada suhu $40^{\circ} \mathrm{C}$, maka tekanan operasi evaporator propana lebih tinggi dari amonia dan tekanan operasi kondensor amonia lebih tinggi dari propana.

\subsection{Karakteristik Tekanan-Entalpi (P-H)} Propana dan Amonia

Amonia dan propana memiliki diagram P$\mathrm{H}$ yang berbeda. Dalam penggambaran diagram $\mathrm{P}-\mathrm{H}$ propana dan amonia, digunakan fitur envelope pada stream analysis Aspen Hysys V11.0.

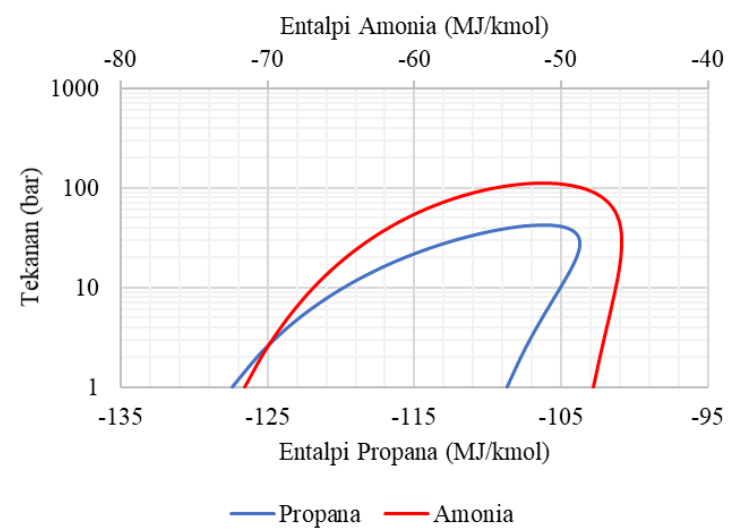

Gambar 5. Diagram P-H propana dan amonia

Untuk memudahkan perbandingan, sumbu absis primer (bawah) dan sekunder (atas) pada Gambar 4 telah diatur sedemikian rupa sehingga amonia dan propana memiliki 
selisih entalpi yang sama yaitu $40 \mathrm{MJ} / \mathrm{kmol}$.

Dari Gambar 4, dapat diketahui bahwa diagram P-H amonia lebih luas dari propana.

Pada tekanan yang sama, kalor laten amonia lebih tinggi dari propana sehingga pada laju alir refrigeran yang sama, amonia mampu mengambil panas dari gas alam dalam jumlah yang lebih banyak daripada propana. Hal ini dapat juga diartikan bahwa untuk mengambil panas gas alam dalam jumlah yang sama, maka kebutuhan laju alir amonia lebih kecil dari propana.

\subsection{Parameter Proses Siklus Refrigerasi Propana dan Amonia pada Kondisi Base Case}

Amonia dan propana memiliki sifat fisik dan kimia yang berbeda sehingga menghasilkan kinerja proses siklus refrigerasi yang berbeda pula. Dalam membandingkan performa refrigeran, tiga parameter bernilai konstan yaitu beban evaporator $100 \mathrm{~kW}$, temperatur evaporator $-20^{\circ} \mathrm{C}$ (base case), dan temperatur kondensor $40^{\circ} \mathrm{C}$ (base case). Perbandingan parameter proses siklus refrigerasi propana dan amonia disajikan pada Tabel 4.

Nilai COP amonia lebih tinggi dari propana dan hal ini menunjukkan keunggulan proses refrigerasi yang menggunakan refrigeran amonia dibandingkan propana (Chebbi dkk., 2013; Nawaz dkk., 2018). COP didefinisikan sebagai rasio beban evaporator terhadap kerja kompresor. Karena beban evaporator bernilai tetap $100 \mathrm{~kW}$ dan kerja kompresor amonia lebih kecil dari propana, maka COP amonia lebih bagus dari propana.

Tabel 4 menunjukkan bahwa laju alir sirkulasi amonia lebih kecil daripada propana. Kebutuhan laju alir refrigeran merupakan fungsi beban evaporator dan kalor laten refrigeran. Seperti yang telah dijelaskan pada sub bab 3.3, kalor laten amonia lebih banyak dari propana pada tekanan yang sama. Meskipun tekanan evaporator propana dan amonia tidak berbeda jauh, tetapi kalor laten yang dihasilkan kedua senyawa tersebut berbeda signifikan. Oleh karena itu, kebutuhan laju alir propana lebih banyak dari amonia.

Tabel 4. Perbandingan parameter proses siklus refrigerasi propana dan amonia

\begin{tabular}{|c|c|c|c|c|}
\hline \multirow{2}{*}{ No } & \multirow{2}{*}{ Parameter } & \multirow{2}{*}{ Satuan } & \multicolumn{2}{|c|}{ Refrigeran } \\
\hline & & & Propana & Amonia \\
\hline 1. & $\begin{array}{l}\text { Coefficient of } \\
\text { performance } \\
\text { (COP) }\end{array}$ & - & 2,24 & 2,45 \\
\hline 2. & Laju alir refrigeran & $\mathrm{kg} / \mathrm{jam}$ & 1489 & 338 \\
\hline 3. & Kerja kompresor & kW & 44,6 & 40,8 \\
\hline 4. & Beban kondensor & $\mathrm{kW}$ & 144,6 & 140,8 \\
\hline 5. & $\begin{array}{l}\text { Tekanan } \\
\text { evaporator }\end{array}$ & bar & 2,4 & 1,9 \\
\hline 6. & $\begin{array}{l}\text { Tekanan } \\
\text { kondensor }\end{array}$ & bar & 13,7 & 15,5 \\
\hline 7. & $\begin{array}{l}\text { Rasio tekanan } \\
\text { masuk dan keluar } \\
\text { kompresor }\end{array}$ & - & 5,6 & 8,2 \\
\hline 8. & $\begin{array}{l}\text { Temperatur inlet } \\
\text { kondensor }\end{array}$ & ${ }^{\circ} \mathrm{C}$ & 60,0 & 187,2 \\
\hline 9. & $\begin{array}{l}\text { Fraksi uap outlet } \\
\text { JT valve }\end{array}$ & - & 0,3981 & 0,2149 \\
\hline 10. & $\begin{array}{l}\text { Kalor laten } \\
\text { evaporator }\end{array}$ & $\mathrm{kJ} / \mathrm{kg}$ & 242 & 1065 \\
\hline
\end{tabular}

Amonia sebagai refrigeran memberikan selisih tekanan kondensor dan evaporator yang lebih lebar daripada propana. Berdasarkan penjelasan sub bab 3.2, tekanan evaporator amonia lebih kecil dari propana karena tekanan jenuhnya lebih rendah dari propana pada suhu $-20^{\circ} \mathrm{C}$. Tekanan kondensor amonia lebih besar dari propana karena tekanan jenuh amonia lebih tinggi dari propana pada suhu $40^{\circ} \mathrm{C}$. Meskipun rasio tekanan masuk dan keluar kompresor propana tidak setinggi amonia, kerja kompresor propana lebih besar jika 
dibandingkan dengan amonia. Hal ini disebabkan laju alir propana lebih besar dari amonia sehingga kebutuhan laju alir mengkompensasi rasio tekanan pada perhitungan kerja kompresor.

Temperatur inlet kondensor propana tidak setinggi amonia. Temperatur inlet kondensor bernilai sama dengan temperatur keluar kompresor. Temperatur merupakan besaran intensif yang tidak dipengaruhi jumlah. Temperatur keluar kompresor bergantung pada rasio tekanan masuk dan keluar kompresor. Karena rasio tekanan kompresor amonia lebih tinggi dari propana, maka temperatur keluar kompresor amonia juga lebih besar dari propana.

Dari Tabel 3, dapat dilihat bahwa meskipun temperatur inlet kondensor amonia lebih tinggi, tetapi beban kondensor amonia lebih kecil jika dibandingkan dengan propana. Hal ini disebabkan karena laju alir sirkulasi propana lebih tinggi dari propana sehingga kebutuhan medium pendingin pada kondensor juga meningkat.

Pada saat terjadi ekspansi secara isentalpik dari tekanan kondensor ke tekanan evaporator, terjadi penguapan propana yang lebih banyak jika dibandingkan dengan penguapan amonia. Hal tersebut dibuktikan dengan fraksi uap propana outlet JT valve yang lebih besar dari amonia. Dari Diagram PH pada Gambar 6, ekspansi amonia dari tekanan 15,5 ke 1,9 bar menghasilkan produk kesetimbangan yang lebih dekat dengan garis cair jenuh daripada produk ekspansi propana dari 13,7 ke 2,4 bar. Akibatnya, amonia yang menguap lebih sedikit daripada propana. Fenomena tersebut juga berarti bahwa lebih banyak amonia fasa cair yang dapat menyerap panas gas alam sehingga kebutuhan laju alir amonia lebih sedikit dari propana.

\subsection{Perbandingan Parameter Proses terhadap Perubahan Temperatur Evaporator dan Kondensor}

Perubahan temperatur kondensor dan evaporator berpengaruh terhadap performa siklus refrigerasi. Dalam analisis sensitivitas, parameter yang menjadi pembanding adalah Tabel 4 dan parameter yang dianalisis sensitivitasnya antara lain COP, laju alir refrigeran, kerja kompresor, beban kondensor, dan fraksi uap outlet $J T$ Valve. Semua hasil sensitivitas dinyatakan dalam persentase terhadap parameter proses pada Tabel 4.

\subsubsection{Analisis Sensitivitas terhadap Perubahan Temperatur Evaporator}

Perubahan temperatur evaporator dilambangkan dengan $\Delta T_{\text {evap }}$ sesuai persamaan (21).

$$
\Delta T_{\text {evap }}=T_{\text {evap }}-\left(-20^{\circ} \mathrm{C}\right)
$$

Angka $-20^{\circ} \mathrm{C}$ merupakan base case temperatur evaporator. Nilai $\Delta T_{\text {evap }}$ diamati pengaruhnya terhadap perubahan nilai parameter proses siklus refrigerasi. Grafik sensitivitas parameter proses terhadap perubahan temperatur evaporator dapat dilihat pada Gambar 7.

Gambar 7 menerangkan bahwa COP dan kalor laten evaporator adalah parameter proses yang memiliki pola berbanding lurus terhadap perubahan temperatur evaporator. COP dan kalor laten evaporator meningkat pada saat terjadi kenaikan temperatur evaporator begitu pula sebaliknya. Parameter lainnya yaitu laju alir refrigeran, kerja kompresor, beban kondensor, dan fraksi uap 
outlet $J T$ valve memberikan nilai yang nyebabkan tekanan evaporator meningkat. berbanding terbalik terhadap perubahan Akibatnya, kerja kompresor untuk mencapai temperatur evaporator. Saat temperatur tekanan jenuh kondensor pada suhu $40^{\circ} \mathrm{C}$ evaporator semakin tinggi, maka nilai menjadi lebih ringan. Keringanan kerja keempat parameter tersebut semakin kompresor tersebut ditandai dengan berkurang. Hal ini berlaku sebaliknya untuk menurunnya kerja kompresor yang dapat keempat parameter tersebut terhadap dilihat pada Gambar 7 (c). Peningkatan penurunan temperatur evaporator. tekanan evaporator juga berdampak pada

Sesuai dengan pembahasan sub bab 3.2, peningkatan COP sesuai Gambar 7 (a). kenaikan temperatur evaporator me-

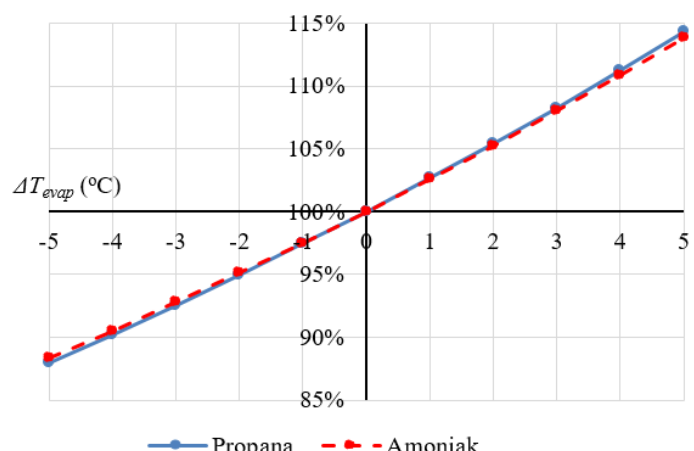

(a)

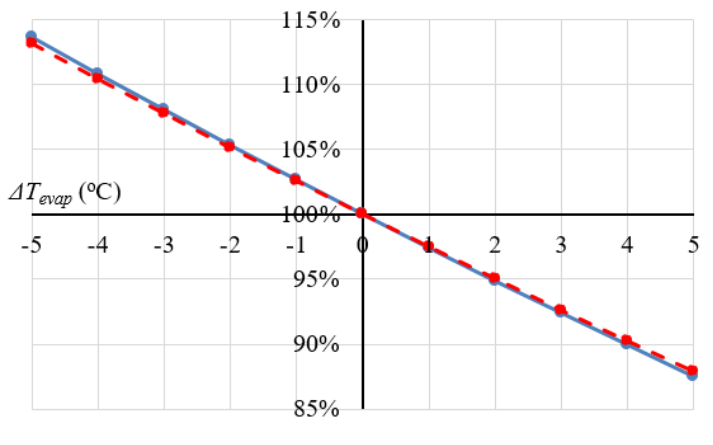

(c)

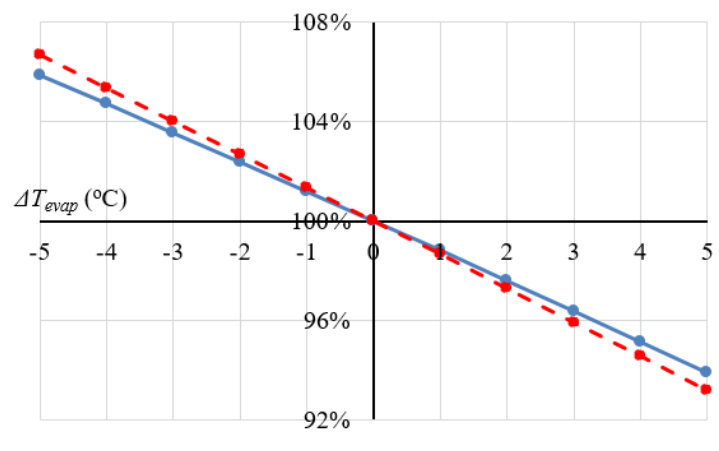

$\longrightarrow$ Propana $-\cdots-$ Amoniak

(e)

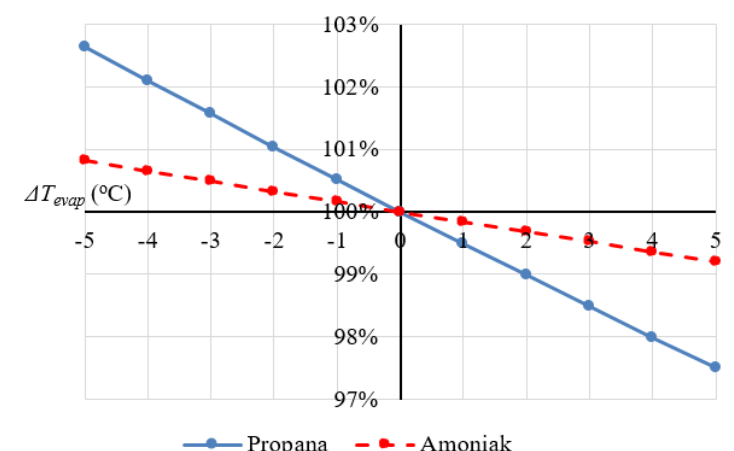

(b)

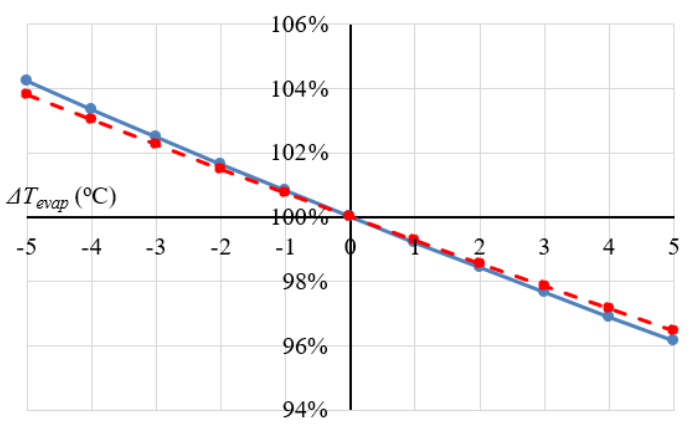

$\longrightarrow$ Propana - - Amoniak

(d)

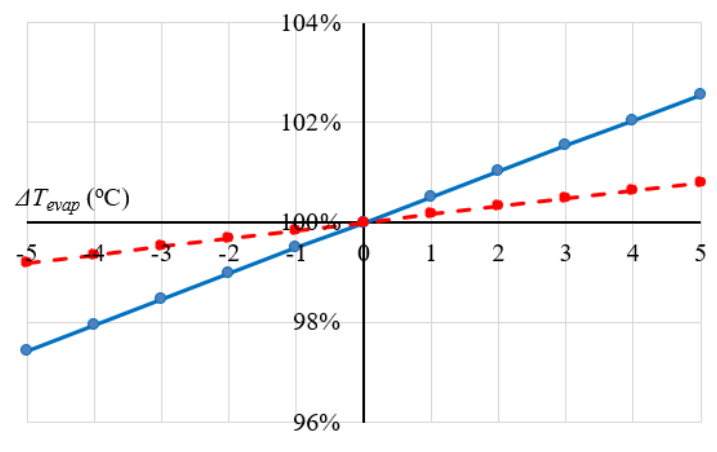

$\longrightarrow$ Propana $-\cdots-$ Amoniak

$(f)$

Gambar 6. Profil sensitivitas (a) COP, (b) laju alir refrigeran, (c) kerja kompresor, (d) beban kondensor, (e) fraksi uap outlet $J T$ valve, dan (f) kalor laten evaporator terhadap perubahan temperatur evaporator 
Refrigeran yang keluar dari evaporator berada dalam kondisi uap jenuh. Kenaikan temperatur evaporator akan diikuti dengan naiknya tekanan evaporator sesuai diagram P-T Gambar 5. Dari diagram P-H pada Gambar 6, dapat diketahui bahwa jika amonia dan propana pada kondisi cair jenuh diekspansi pada kondisi isentalpik sampai ke tekanan akhir yang semakin rendah, maka kedua refrigeran tersebut semakin menjauh dari kondisi cair jenuh. Akibatnya, semakin banyak fraksi uap yang terbentuk sesuai Gambar 7 (e) dan semakin rendah kalor laten yang dapat dimanfaatkan untuk mengambil panas gas alam. Fenomena kalor laten tersebut digambarkan pada Gambar 7 (f). Karena beban evaporator bernilai tetap 100 $\mathrm{kW}$, maka laju alir refrigeran yang diperlukan semakin banyak pada saat tekanan evaporator turun akibat penurunan temperatur evaporator. Hal ini sesuai dengan Gambar 7 (b).

Gambar 7 (d) menunjukkan bahwa beban kondensor menurun seiring dengan meningkatnya temperatur evaporator. Karena temperatur kondensor dijaga tetap, maka tekanan kondensor juga bernilai konstan sehingga kalor laten yang diperlukan untuk mencairkan refrigeran juga tidak berubah. Oleh karena itu, beban kondensor hanya berpengaruh pada laju alir refrigeran pada temperatur kondensor yang tetap. Semakin tinggi temperatur evaporator, maka laju alir refrigeran semakin sedikit karena kalor latennya berkurang.

Gambar 7 (a), 7 (b), 7 (c) 7 (d), dan 7 (f) menunjukkan bahwa COP, laju alir refrigeran, kerja kompresor, beban kondensor, dan kalor laten evaporator propana lebih sensitif terhadap perubahan temperatur evaporator dibandingkan amonia. Khusus pada fraksi uap outlet $J T$ valve, amonia memiliki sensitivitas yang lebih tinggi jika dibandingkan dengan propana sesuai dengan Gambar 7 (e). Merujuk pada diagram P-H Gambar 6, garis cair jenuh propana lebih miring ke kanan daripada amonia sehingga hasil ekspansi propana selalu menghasilkan kondisi yang lebih dekat dengan cair jenuh dibandingkan dengan hasil ekspansi amonia. Oleh karena itu, pada kenaikan temperatur evaporator yang sama, perubahan fraksi uap hasil ekspansi amonia lebih banyak dari propana.

\subsubsection{Analisis Sensitivitas terhadap Perubahan Temperatur Kondensor}

Perubahan temperatur kondensor dilambangkan dengan $\Delta T_{\text {kond. }}$ Perubahan temperatur kondensor dimodelkan sebagai Persamaan (22).

$$
\Delta T_{\text {kond }}=T_{\text {kond }}-40^{\circ} \mathrm{C}
$$

Angka $40^{\circ} \mathrm{C}$ adalah base case temperatur kondensor. Nilai $\Delta T_{\text {kond }}$ diamati pengaruhnya terhadap signifikansi perubahan parameter proses. Gambar 8 (a) sampai dengan 8 (e) berikut menunjukkan hasil sensitivitas parameter proses terhadap perubahan temperatur kondensor.

Gambar 8 menunjukkan bahwa hanya COP yang berbanding terbalik terhadap perubahan temperatur kondensor. Saat temperatur kondensor meningkat, maka COP turun dan hal ini berlaku sebaliknya. Laju alir refrigeran, kerja kompresor, beban kondensor, dan fraksi uap outlet $J T$ valve berbanding lurus dengan kenaikan temperatur kondensor. Saat temperatur kondensor berkurang, maka terjadi penurunan nilai untuk parameter selain COP. 


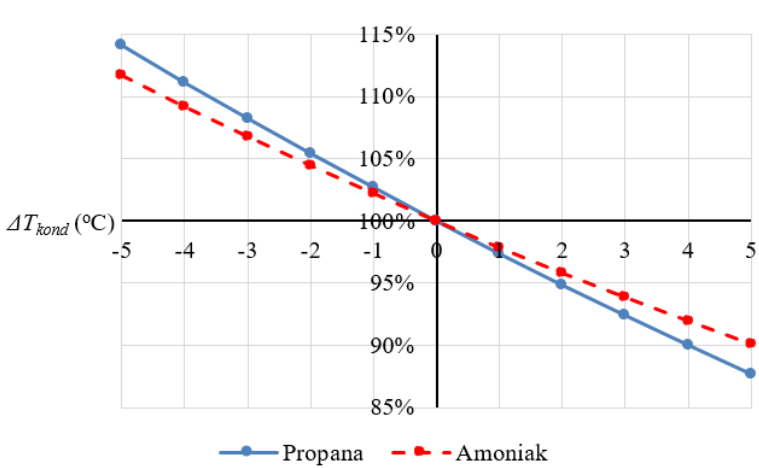

(a)

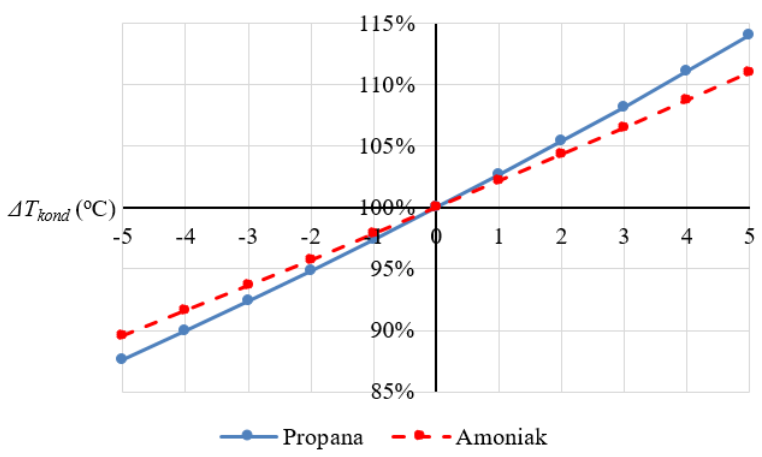

(c)

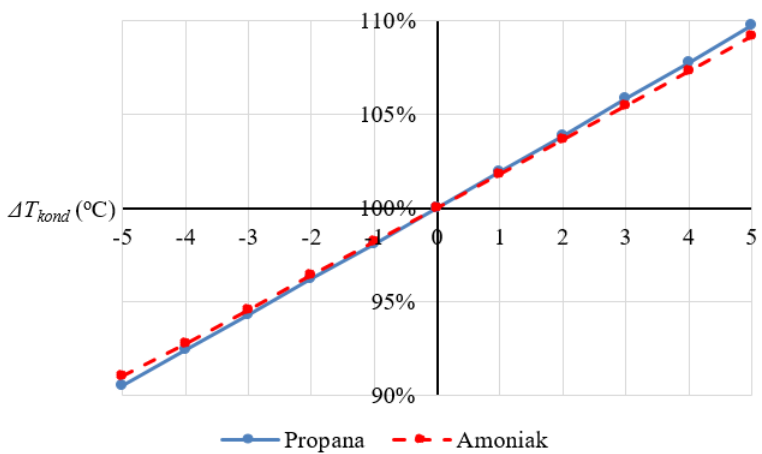

(e)

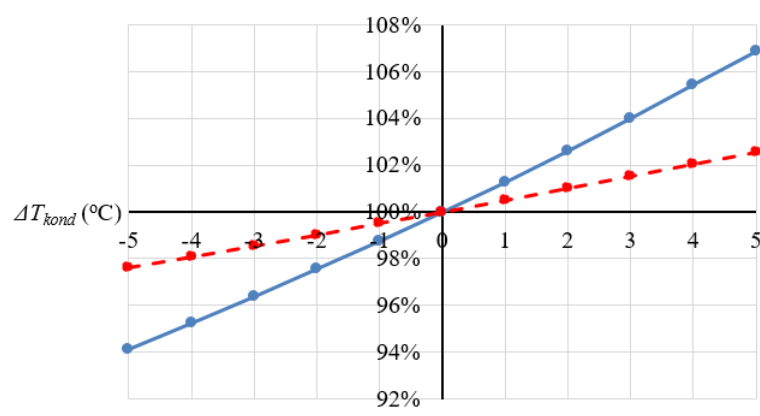

$\longrightarrow$ Propana - - Amoniak

(b)

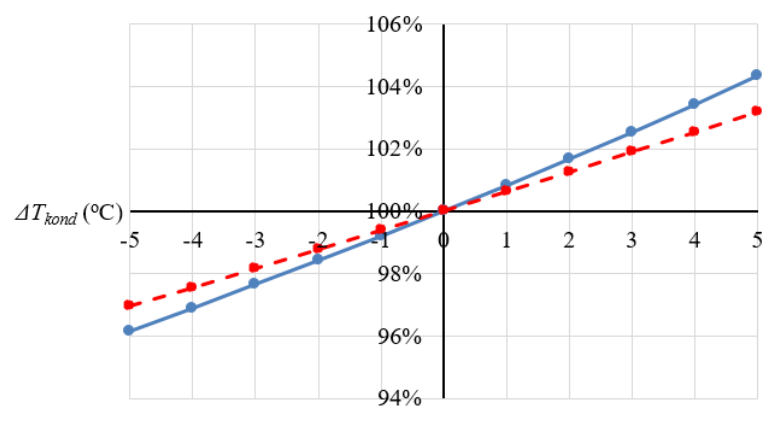

$\longrightarrow$ Propana - - Amoniak

(d)

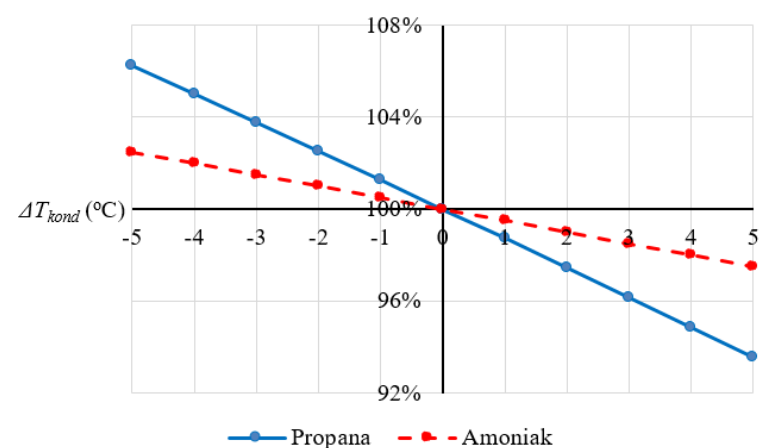

(f)

Gambar 7. Profil sensitivitas (a) COP, (b) laju alir refrigeran, (c) kerja kompresor, (d) beban kondensor, (e) fraksi uap outlet $J T$ valve, dan (f) kalor laten evaporator terhadap perubahan temperatur kondensor

Outlet kondensor adalah refrigeran cair jenuh sehingga tekanan operasinya dapat diketahui untuk setiap temperatur kondensor yang diinginkan. Berdasarkan diagram P-T Gambar 5, temperatur kondensor yang meningkat menyebabkan kenaikan tekanan jenuh sehingga tekanan outlet kompresor juga meningkat. Kenaikan tekanan outlet kompresor ini menyebabkan kerja kompresor semakin tinggi dan hal ini terbukti pada Gambar 8 (c). Pada beban evaporator yang sama, peningkatan kerja kompresor tersebut menyebabkan nilai COP turun sesuai Gambar 8 (a).

Berdasarkan diagram P-H pada Gambar 6, untuk tekanan akhir ekspansi yang sama, maka kenaikan tekanan inlet ekspansi menyebabkan refrigeran hasil ekspansi semakin jauh dari kondisi cair jenuh. Efek yang timbul dari peristiwa ini adalah meningkatnya fraksi uap hasil ekspansi sesuai Gambar 8 (e) dan berkurangnya kalor laten evaporator sesuai Gambar 8 (f). Penguapan yang semakin banyak menyebabkan hanya 
sedikit cairan hasil ekspansi yang dapat dimanfaatkan untuk mengambil panas gas alam di evaporator. Untuk mengkompensasi hal tersebut, maka laju alir refrigeran harus ditingkatkan pada beban evaporator yang sama jika temperatur kondensor meningkat. Hal ini merupakan penjelasan dari Gambar 8 (b).

Dari Gambar 8 (d), diketahui bahwa terjadi peningkatan beban kondensor yang sebanding dengan kenaikan temperatur kondensor. Telah diketahui bahwa temperatur kondensor yang semakin tinggi menyebabkan tekanan kondensor yang semakin tinggi meskipun kalor laten semakin rendah. Karena peningkatan laju alir refrigeran lebih tinggi dari penurunan panas laten kondensasi, maka beban kondensor meningkat saat temperatur kondensor semakin tinggi.

Gambar 8 (a) sampai (f) menunjukkan respon siklus refrigerasi propana dan amonia terhadap perubahan temperatur kondensor. Dapat disimpulkan bahwa saat terjadi perubahan temperatur kondensor, maka performa siklus refrigerasi propana lebih sensitif daripada amonia.

\subsubsection{Perbandingan Sensitivitas Parameter Proses Sikus Refrigerasi Propana dan Amonia}

Propana dan amonia memberikan sensitivitas parameter proses yang berbeda terhadap perubahan temperatur evaporator dan kondensor. Perbandingan tersebut dirangkum pada Tabel 5 .

Pada siklus refrigerasi propana, rentang sensitivitas semua parameter proses akibat temperatur kondensor lebih lebar dibandingkan rentang sensitivitas akibat temperatur evaporator. Pada siklus refrigerasi amonia, rentang sensitivitas COP, kerja kompresor, dan beban kondensor akibat temperatur evaporator lebih lebar daripada rentang sensitivitas akibat temperatur kondensor. Selain itu pada siklus refrigerasi amonia, rentang sensitivitas laju alir, fraksi uap outlet $J T$ valve, dan kalor laten evaporator akibat temperatur kondensor lebih lebar daripada rentang senstivitas akibat temperatur evaporator.

\subsubsection{Pemodelan COP sebagai Fungsi Perubahan Temperatur Evaporator dan Kondensor}

Untuk menggambarkan performa refrigeran propana dan amonia secara umum, dibuat persamaan yang merumuskan nilai COP sebagai fungsi perubahan temperatur kondensor $\left(\Delta T_{\text {kond }}\right)$ dan perubahan temperatur evaporator ( $\left.\Delta T_{\text {evap }}\right)$. Nilai COP dihitung dari hasil kali antara nilai COP base case dan persentase perubahan nilai COP pada suatu temperatur evaporator atau kondensor tertentu. Performa COP yang menjadi acuan adalah 2,24 untuk propana dan 2,45 untuk amonia pada $T_{\text {evap }}=-20^{\circ} \mathrm{C}$ $\left(\Delta T_{\text {evap }}=0^{\circ} \mathrm{C}\right)$ dan $T_{\text {kond }}=40^{\circ} \mathrm{C}\left(\Delta T_{\text {kond }}=0^{\circ} \mathrm{C}\right)$. Untuk memodelkan nilai COP, maka profil perubahan COP pada berbagai perubahan temperatur evaporator (Gambar 7 (a)) digabung dengan grafik perubahan COP sebagai fungsi perubahan temperatur kondensor (Gambar 8 (a)). Profil perubahan COP pada berbagai temperatur evaporator dan temperatur kondensor ditunjukkan oleh Gambar 9. Untuk menyederhanakan gambar, maka perubahan COP pada Gambar 9 hanya menunjukkan perubahan temperatur kondensor $-5^{\circ} \mathrm{C}$ dan $+5^{\circ} \mathrm{C}$ yang mewakili perubahan temperatur minimal dan maksimal. 
Tabel 5. Perbandingan sensitivitas parameter proses refrigeran propana dan amonia

\begin{tabular}{llllll}
\hline \multirow{2}{*}{ No } & \multirow{2}{*}{ Parameter Proses } & \multicolumn{2}{c}{ Propana } & \multicolumn{2}{c}{ Amonia } \\
\cline { 3 - 6 } & & Pengaruh $\Delta T_{\text {evap }}$ & Pengaruh $\Delta T_{\text {kond }}$ & Pengaruh $\Delta T_{\text {evap }}$ & Pengaruh $\Delta T_{\text {kond }}$ \\
\hline 1. & COP & $88,0 \%-114,3 \%$ & $87,7 \%-114,2 \%$ & $88,4 \%-113,8 \%$ & $90,1 \%-111,7 \%$ \\
2. & Kerja kompresor & $87,5 \%-113,6 \%$ & $87,6 \%-114,0 \%$ & $87,9 \%-113,2 \%$ & $89,5 \%-111,0 \%$ \\
3. & Beban kondensor & $96,1 \%-104,2 \%$ & $96,2 \%-104,3 \%$ & $96,5 \%-103,8 \%$ & $97,0 \%-103,2 \%$ \\
4. & Laju alir & $97,5 \%-102,6 \%$ & $94,1 \%-106,9 \%$ & $99,2 \%-100,8 \%$ & $97,6 \%-102,6 \%$ \\
5. & Fraksi uap outlet JT valve & $93,9 \%-105,9 \%$ & $90,5 \%-109,8 \%$ & $93,2 \%-106,7 \%$ & $91,0 \%-109,2 \%$ \\
6. & Kalor laten evaporator & $97,4 \%-102,6 \%$ & $93,6 \%-106,3 \%$ & $99,2 \%-100,8 \%$ & $97,5 \%-102,5 \%$ \\
\hline
\end{tabular}

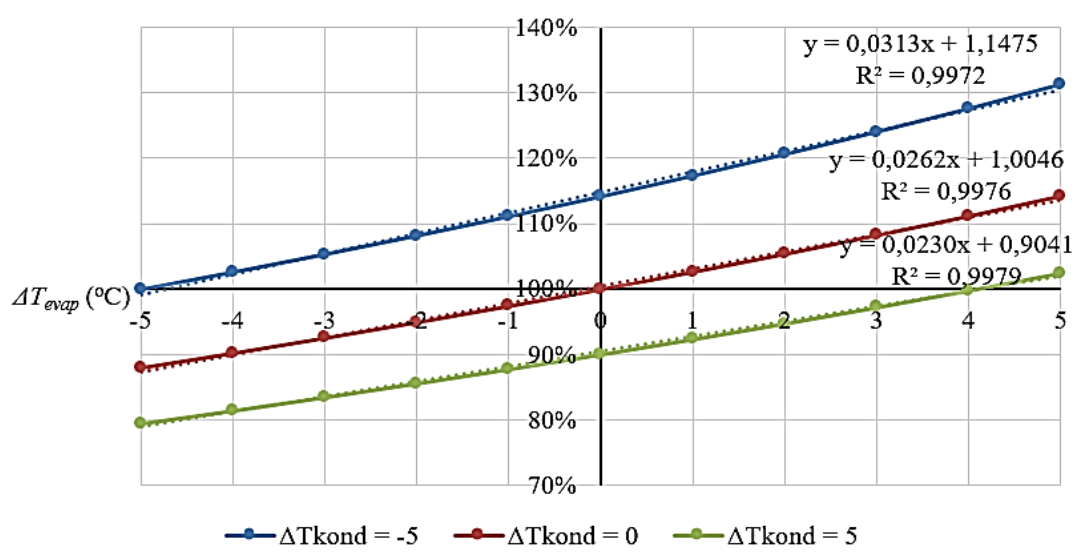

(a)

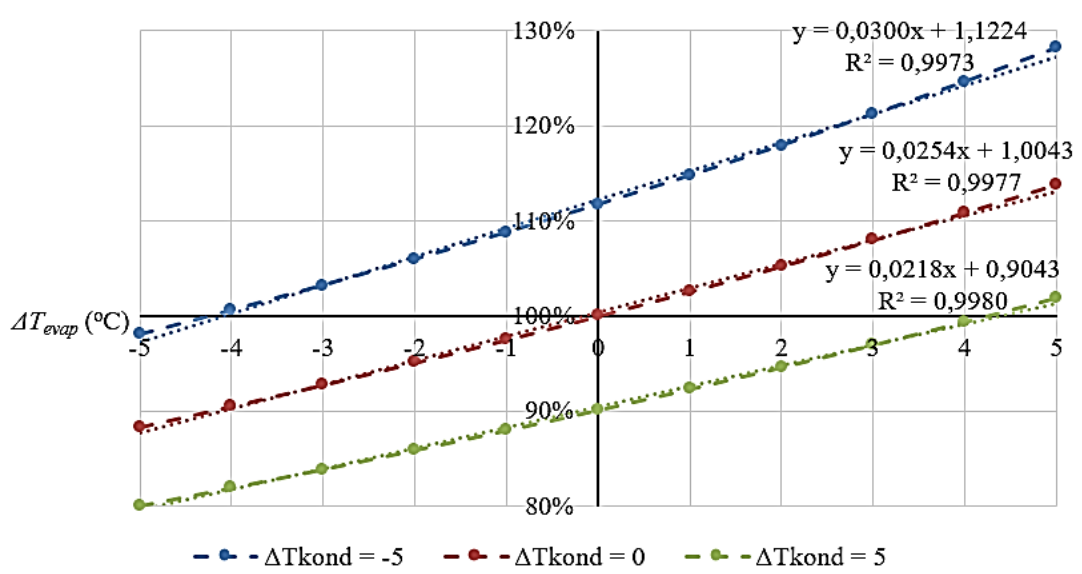

(b)

Gambar 8. Profil sentivitas COP (a) propana (b) amonia pada berbagai temperatur evaporator dan kondensor

Profil sensitivitas COP merupakan sebuah garis lurus sehingga dapat dimodelkan sebagai persamaan linier yang melibatkan gradien $(m)$ dan konstanta (c). Pada perubahan temperatur kondensor $\left(\Delta \mathrm{T}_{\text {kond }}\right)$ yang sama, berlaku hubungan linier seperti ditunjukkan pada Persamaan (23).

$$
\text { persentase } C O P=m \cdot \Delta T_{\text {evap }}+c
$$

Merujuk pada Gambar 9, nilai gradien grafik dan konstanta akan berbeda untuk setiap $\Delta T_{\text {kond. Nilai gradien }(\mathrm{m}) \text { dapat dihitung }}$ dengan menggunakan fungsi slope sedangkan nilai konstanta (c) berasal dari fungsi intercept pada Microsoft Excel 365. Kesesuaian model regresi $\left(R^{2}\right)$ dianalisa dengan menggunakan fungsi RSQ pada Microsoft Excel 365. 
Tabel 6. Hasil kalkulasi nilai gradien dan konstanta propana pada berbagai $\Delta T_{\text {kond }}$

\begin{tabular}{lcccc}
\hline No & $\Delta T_{\text {kond }}\left({ }^{\circ} \mathrm{C}\right)$ & $m$ & $c$ & $R^{2}$ \\
\hline 1 & -5 & 0,0313 & 1,1475 & 0,9972 \\
2 & -4 & 0,0302 & 1,1171 & 0,9973 \\
3 & -3 & 0,0291 & 1,0877 & 0,9974 \\
4 & -2 & 0,0281 & 1,0592 & 0,9975 \\
5 & -1 & 0,0272 & 1,0315 & 0,9976 \\
6 & 0 & 0,0262 & 1,0046 & 0,9976 \\
7 & 1 & 0,0254 & 0,9784 & 0,9977 \\
8 & 2 & 0,0245 & 0,9530 & 0,9978 \\
9 & 3 & 0,0237 & 0,9282 & 0,9978 \\
10 & 4 & 0,0230 & 0,9041 & 0,9979 \\
11 & 5 & 0,0222 & 0,8806 & 0,9979 \\
\hline
\end{tabular}

Nilai $\Delta T_{\text {kond }}$ yang berbeda memberikan nilai gradien $(m)$ dan konstanta $(c)$ yang berbeda pula. Supaya persamaan (23) menjadi persamaan global yang berlaku untuk berbagai perubahan temperatur evaporator dan perubahan temperatur kondensor, maka nilai gradien $(m)$ dan konstanta ( $c$ ) diubah sebagai fungsi perubahan temperatur kondensor $\left(\Delta T_{\text {kond }}\right)$. Dengan menggunakan fungsi slope dan intercept, persamaan gradien dan konstanta untuk refrigeran propana ditunjukkan oleh Persamaan (24) dan (25).

$m=-9,0522 \times 10^{-4} \Delta T_{\text {kond }}+0,0265 ; R^{2}=0,9957$

$c=-0,0266 \Delta T_{\text {kond }}+1,0084 ; R^{2}=0,9984$

Persamaan (24) dan (25) disubstitusi ke persamaan (23) sehingga didapat model persentase COP propana seperti ditunjukkan pada Persamaan (26).

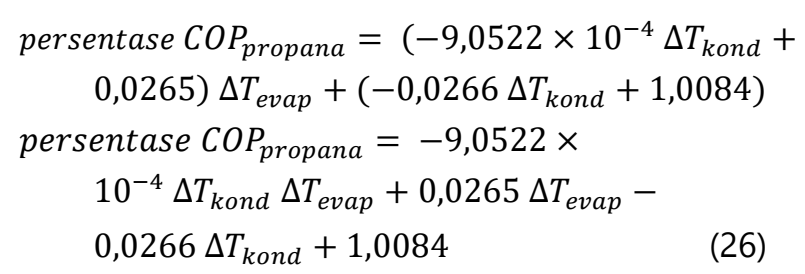

COP propana yang dijadikan pembanding adalah 2,24 sehingga persamaan (26) dapat diubah menjadi Persamaan (27).

$$
\begin{gathered}
C O P_{\text {propana }}=-2,0277 \times 10^{-3} \Delta T_{\text {kond }} \Delta T_{\text {evap }}+ \\
0,0594 \Delta T_{\text {evap }}-0,0596 \Delta T_{\text {kond }}+2,2588
\end{gathered}
$$

Untuk amonia, nilai gradien dan konstanta yang didapat tentu berbeda dengan nilai yang didapat dari propana. Hasil kalkulasi nilai gradien dan konstanta pada berbagai $\Delta T_{\text {kond }}$ untuk amonia ditampilkan pada Tabel 7.

Tabel 7. Hasil kalkulasi nilai gradien dan konstanta amonia pada berbagai $\Delta \mathrm{T}_{\text {kond }}$

\begin{tabular}{lcccc}
\hline No & $\Delta T_{\text {kond }}\left({ }^{\circ} \mathrm{C}\right)$ & $m$ & $c$ & $R^{2}$ \\
\hline 1 & -5 & 0,0300 & 1,1224 & 0,9973 \\
2 & -4 & 0,0290 & 1,0971 & 0,9974 \\
3 & -3 & 0,0280 & 1,0727 & 0,9975 \\
4 & -2 & 0,0271 & 1,0491 & 0,9976 \\
5 & -1 & 0,0262 & 1,0264 & 0,9976 \\
6 & 0 & 0,0254 & 1,0043 & 0,9977 \\
7 & 1 & 0,0246 & 0,9830 & 0,9978 \\
8 & 2 & 0,0238 & 0,9624 & 0,9979 \\
9 & 3 & 0,0231 & 0,9424 & 0,9979 \\
10 & 4 & 0,0224 & 0,9230 & 0,9980 \\
11 & 5 & 0,0218 & 0,9043 & 0,9980 \\
\hline
\end{tabular}

Dengan cara yang sama seperti propana, persamaan gradien grafik dan konstanta amonia ditampilkan pada Persamaan (28) dan (29).

$m=-8,2511 \times 10^{-4} \Delta T_{\text {kond }}+0,0256 ; R^{2}=0,9955$

$c=-0,0218 \Delta T_{\text {kond }}+1,0079 ; R^{2}=0,9979$

Persamaan (23) yang mendapat substitusi $m$ dan $c$ dari Persamaan (28) dan (29) merupakan model persamaan persentase COP untuk amonia (persamaan (30)).

$$
\begin{aligned}
& \text { persentase COP amoniak }=-8,2511 \times \\
& 10^{-4} \Delta T_{\text {kond }} \Delta T_{\text {evap }}+0,0256 \Delta T_{\text {evap }}- \\
& 0,0218 \Delta T_{\text {kond }}+1,0079
\end{aligned}
$$


COP amonia pembanding adalah 2,45 sehingga nilai COP dapat ditentukan dari Persamaan (30) yang dikali dengan 2,45 sehingga menghasilkan Persamaan (31).

$$
\begin{gathered}
C O P_{\text {amoniak }}=-2,0215 \times 10^{-3} \Delta T_{\text {kond }} \Delta T_{\text {evap }}+ \\
0,0627 \Delta T_{\text {evap }}-0,0534 \Delta T_{\text {kond }}+2,4694
\end{gathered}
$$

Persentase COP propana pada Persamaan (26) dan COP amonia pada Persamaan (30) menunjukkan bahwa setiap konstanta persentase COP amonia lebih kecil daripada setiap konstanta persentase COP propana. Secara kuantitatif, COP propana lebih sensitif terhadap perubahan temperatur kondensor dan evaporator dibandingkan dengan COP amonia.

\section{Kesimpulan}

Pada beban evaporator, temperatur evaporator, dan temperatur kondensor yang sama, performa refrigeran amonia lebih baik dari propana karena COP amonia lebih tinggi. Saat terjadi perubahan temperatur evaporator pada temperatur kondensor yang konstan, siklus refrigerasi amonia lebih stabil daripada propana. Sedangkan saat terjadi perubahan temperatur kondensor pada temperatur evaporator yang konstan, siklus refrigerasi amonia juga lebih stabil daripada propana. Pemodelan COP sebagai fungsi perubahan temperatur evaporator dan kondensor telah dilakukan. Hasil pemodelan tersebut menunjukkan bahwa COP amonia lebih stabil terhadap perubahan temperatur evaporator dan kondensor.

\section{Daftar Notasi}

$$
\begin{array}{ll}
A & =\text { konstanta Antoine } \\
B & =\text { konstanta Antoine } \\
C & =\text { konstanta Antoine }
\end{array}
$$

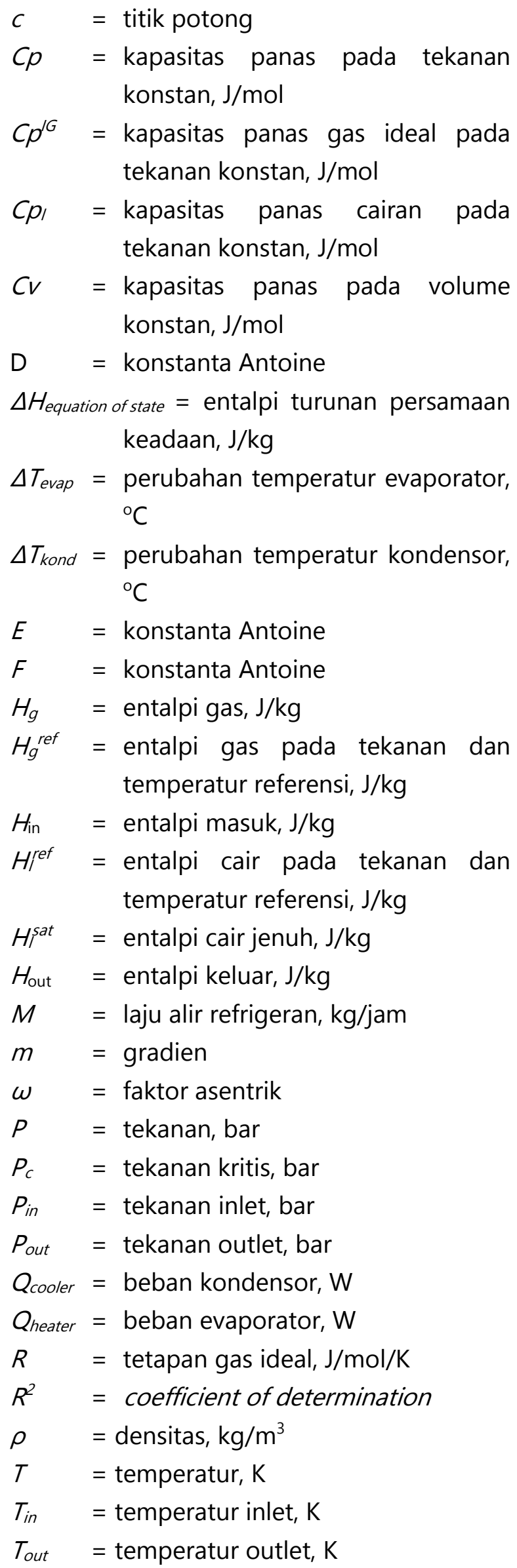




$$
\begin{array}{ll}
T_{\text {ref }} & =\text { temperatur referensi, } \mathrm{K} \\
t & =\text { waktu, detik } \\
T_{c} & =\text { temperatur kritis, }{ }^{\circ} \mathrm{C} \\
T_{\text {evap }} & =\text { temperatur evaporator, }{ }^{\circ} \mathrm{C} \\
T_{\text {kond }} & =\text { temperatur kondensor, }{ }^{\circ} \mathrm{C} \\
V & =\text { volume, } \mathrm{m}^{3} \\
W & =\text { kerja kompresor, } \mathrm{W} \\
Z & =\text { faktor kompresibilitas }
\end{array}
$$

\section{Ucapan Terima Kasih}

Penulis menyampaikan ucapan terima kasih kepada:

1. Dr. Tri Partono Adhi yang telah memberikan ide kepada penulis tentang topik penulisan artikel.

2. Program Studi Teknik Kimia ITB yang telah menyediakan lisensi akademik Aspen Hysys untuk simulasi.

3. Lembaga Pengelola Dana Pendidikan Republik Indonesia (LPDP RI) sebagai penyandang dana penelitian.

\section{Daftar Pustaka}

Aftab, A., Unar, I. N., Mahar, H., Almani, S. M., Hussain, S., dan Siddique, M., 2016, Modeling of refrigeration based hydrocarbon dew point control plant, Sci.Int., 28(4), 3603-3608.

Al Shehhi, A., Varghese, M. J., Rao, L., dan Walke, S., 2019, Process simulation and optimization of natural gas dehydration process using aspen hysys, Int. J. Innov. Technol. Explor. Eng., 8 (9), 644-649.

Chebbi, R., Qasim, M., Darwish, N. A., dan Ashraf, M. T., 2013, Optimization and costoriented comparison of ammonia- and propane-compression refrigeration for the recovery of natural gas liquids, Energy Technol., 1 (10), 573-580.
Eckhoff, R. K., Ngo, M., dan Olsen, W., 2010, On the minimum ignition energy (MIE) for propane/air, J. Hazard. Mater., 175 (1-3), 293-297.

El Mawgoud, H.A., Elshiekh, T.M. dan Khalil, S.A., 2015, Process simulation for revamping of a dehydration gas plant, Egypt. J. Pet., 24 (4), 475-482.

Elhady, A. A. A., 2005, Operating experiences of DEG and MEG for hydrate and dewpoint control in gas production offshore mediterranean, 2005 Int. Pet. Technol. Conf. Proc., 123-128.

Elyas, R. dan Li, Z. H., 2017, Modeling of a Dew Point Control Unit With UniSim Design, di: Foo, D. C., Chemmangattuvalappil, N., Ng, D. K. S., Elyas, R., Chen, C., Elms, R. D., Lee, H., Chien, I., Chong, S., dam Chong, C. H., Chemical Engineering Process Simulation, Elsevier Inc, pp. 119-135.

Hidayat, M., Hartanto, D. T., Azis, M. M., dan Sutijan, S., 2020, Studi Penambahan Etilena Glikol dalam Menghambat Pembentukan Metana Hidrat pada Proses Pemurnian Gas Alam, J. Rekayasa Proses, 14 (2), 198.

Horbaniuc, B.D., 2004, Refrigeration and AirConditioning, 5, 261-289.

Kobayashi, H., Hayakawa, A., Somarathne, K. D. K. A., dan Okafor, E. C., 2019, Science and technology of ammonia combustion, Proc. Combust. Inst., Elsevier Inc., 37 (1), 109133.

Lim, W., Choi, K., dan Moon, I., 2013, Current status and perspectives of Liquefied Natural Gas (LNG) plant design, Ind. Eng. Chem. Res., 6 Maret.

Makogon, Y. F., 2010, Natural gas hydrates A promising source of energy, J. Nat. Gas Sci. Eng., Elsevier B.V, 2 (1), 49-59.

Mokhatab, S., Mak, J. Y., Valappil, J. V., dan Wood, D.A., 2014, Handbook of Liquefied 
Natural Gas, First Edit., Gulf Professional Publishing.

Mokhatab, S., Northrop, S., dan Mitariten, M., 2017, Controlling the Hydrocarbon Dew Point of Pipeline Gas, Digit. Refin., 1-9.

Nasir, Q., Suleman, H., dan Elsheikh, Y. A., 2020, A review on the role and impact of various additives as promoters/ inhibitors for gas hydrate formation, J. Nat. Gas Sci. Eng., 76, No. 103211, https://doi.org/ 10.1016/j.jngse.2020.103211

Nawaz, K., Raza, M. A., dan Abdelaziz, O., 2018, Ammonia and propane as natural refrigerants for heat pump applications, Refrig. Sci. Technol., 2018-June (c), 604611.
Shoaib, A. M., Bhran, A. A., Awad, M. E., ElSayed, N.A., dan Fathy, T., 2018, Optimum operating conditions for improving natural gas dew point and condensate throughput, J. Nat. Gas Sci. Eng., 49, 324330.

Smith, J. M., Ness, H. C. V., Abott, M. M., dan Swihart, M. T., 2017, Introduction to chemical engineering thermodynamics, 8th edition, McGraw-Hill Education, New York.

Smith, R., 2005, Chemical Process Design and Integration, Wiley.

Verkamp, F. J., Hardin, M. C., dan Williams, J. R., 1967, Ammonia combustion properties and performance in gas-turbine burners, Symp. Combust., 11 (1), 985-992. 